\title{
Best practice in research - overcoming common challenges in phytopharmacological research
}

Heinrich, Michael ${ }^{1 . *}$; Appendino, Giovanni ${ }^{2, \&}$; Efferth, Thomas ${ }^{3, \&}$, Fürst, Robert ${ }^{4, \&}$; Izzo, Angelo A., ${ }^{5, \&}$; Kayser, Oliver ${ }^{6, \&}$; Pezzuto, John M.7,\&.; Viljoen, Alvaro ${ }^{8,9 \&}$

1) 'Pharmacognosy and Phytotherapy', UCL School of Pharmacy, 29 - 39 Brunswick Sq., London WC1N 1AX, Tel.: 0044-20-7753 5844 /Email:: m.heinrich@ucl.ac.uk

2) Dipartimento di Scienze del Farmaco, Largo Donegani 2, 28100 Novara, Italy, Tel: +390321 375 744/Email: giovanni.appendino@uniupo.it

3) Department of Pharmaceutical Biology, Institute of Pharmacy and Biochemistry, Johannes Gutenberg University, Staudinger Weg 5, 55128 Mainz, Germany, efferth@uni-mainz.de

4) Institute of Pharmaceutical Biology, Faculty of Biochemistry, Chemistry and Pharmacy, Goethe University Frankfurt, Max-von-Laue-Str. 9, 60438 Frankfurt, Germany

5) Department of Pharmacy, School of Medicine and Surgery, University of Naples Federico II, via D Montesano 49, Naples, Italy

6) Technical Biochemistry, TU Dortmund University, Emil-Figge-Strasse 66, 44227 Dortmund, Germany, Tel.: 0049-151 40429743 /Email: oliver.kayser@tudortmund.de

7) Arnold \& Marie Schwartz College of Pharmacy and Health Sciences, Long Island University, 75 DeKalb Avenue, Brooklyn, New York, USA, Tel.: +1-718-4881004/Email: John.Pezzuto@liu.edu

8) Department of Pharmaceutical Sciences, Faculty of Science, Tshwane University of Technology, Private Bag X680, Pretoria 0001, South Africa.

9) SAMRC Herbal Drugs Research Unit, Faculty of Science, Tshwane University of Technology, Private Bag X680, Pretoria 0001, South Africa.

$\&$ - These authors all contributed equally in their role as senior editors / editors-in-chief of the journals who have joined in this consensus statement 
Background .The pharmacology, toxicology and pharmacokinetics of bioactive preparations derived from natural sources has become a flourishing field of research. However, researching complex extracts and natural products faces numerous challenges. More broadly in recent years the critique of pharmacological research, and specifically its design, the methods used and reporting has intensified. .

Aims: This consensus document provides a perspective on what constitutes best practice in pharmacological research on bioactive preparations derived from natural sources, providing a perspective of what the leading specialist journals in the field consider as the core characteristics of good research.

Approach ('Methods'). The editors in chief of seven journals developed this best practice statement in an iterative process. A first draft of the guidelines (prepared by $\mathrm{MH}$ ) was then discussed and amended by the other authors.

Outcomes. Core to this contribution is a table which provides detailed advice including simple points like a use of appropriate controls and the full taxonomic validity of the material under investigation (see also below), to the relevance of the model for the question being researched (e.g. can specific in silico or in vitro models really say s.th. about the species antiinflammatory activity?). Therefore, obviously, researchers must pay detailed attention to reporting and discussing such studies. This information must be discussed critically (as much as it is possible based on the published papers) in terms of their scientific quality and validity. While these points are obvious, as editors we are aware that they are often not properly implemented.

Conclusion. We call for an approach which incorporates a careful design, meticulous execution and a detailed reporting of studies focusing on the pharmacology / bioactivity of bioactive preparations. Clearly testable research questions must be developed and investigated experimentally. As the founder of pharmacology Claude Bernard put it already in 1865: ' .... either the experimenter's hypothesis will be disproved or it will be proved by experiment. When experiment disproves its preconceived ideas, the experimenter must discard or modify it.'

\section{Introduction}


'Experimenters must doubt, avoid fixed ideas, and always keep their freedom of mind' [Bernard 1957: 35 (French original 1865)]

The critique of research on pharmacology, toxicology and pharmacokinetics of bioactive substances has intensified over the years. Challenges to these approaches are numerous and in 2005 Ionides claimed "Simulations show that for most study designs and settings, it is more likely for a research claim to be false than true." In other words "It can be proven that most claimed research findings are false." (Ionides 2005) One cannot be more direct in stating the problem of reproducibility in the designing, analysing and reporting research. Moreover, for many current scientific fields, claimed research findings may often be simply accurate measures of the prevailing bias." (Ioannidis 2005, 0696). Think, for example, of a period of around 30 years, when it was thought that the human diploid chromosome number was 48 , and essentially all work conducted by geneticists was considered flawed, until the correct number of 46 was reported in 1956 (cf. Harper 2006).

In this best practice statement we look specifically at the challenges faced in the area of natural products research and medicinal plant preparations with respect to their pharmacological study. The huge field of pharmacology is no exception to this lack of reproducibility and this has resulted in pharmacological journals publishing a range of best practice guidelines or consensus documents (e.g., Mullane et al. 2015). Our observations aim to help researchers develop and report their pharmacological findings and to remain cognizant of the challenges in the complex workflow which defines natural product research. Toxicological and pharmacokinetic studies are not covered here.

Focusing on medicinal plant research, several added challenges need to be recognised. First and foremost, the field is unique in tackling pharmacological and biological activities of complex mixtures of active and inactive natural products. If we want the use of medicinal plants and later as regulated herbal medicinal products (rational phytotherapy) to be a science-based medical practice, "controlled clinical trials or in rigorous biomedical studies" (Heinrich 2013) are needed. The interpretation and acceptance of such evidence for phytotherapeutic practices varies. This is often driven by regulatory agencies, which require different types and levels of evidence, but in some countries/regions products are accepted as regulated (medical) substances, while in others they remain, in essence, unregulated or accepted as "traditionally used preparations" (Bodecker et al. 2005; WHO 2005). As editors, it is our broader aim to support the use of nature-derived products as evidence-based medicines whether they are used as extracts (phytotherapy/ethnopharmacology) or as pure 
and defined natural products. Equally important, there is a long-standing consensus that the interface between food and medicines is fluid and culturally defined. For pharmacological research, this poses particular challenges in deciding whether an intervention or pharmacological experiment actually focuses on a potential use as a healthy food (e.g., nutraceutical) or a medicine.

As editors, we have seen a large number of manuscripts and, while all the above challenges provide a crucial wider context, we also have seen numerous examples of good and bad practice in designing, analysing and reporting pharmacological studies. The aim of this review is to provide guidelines for best practice encouraging authors to ascertain that they follow these recommendations. These are not rigorously defined minimal standards, but criteria to be met in order to publish in Fitoterapia, Frontiers in Pharmacology (Sect.

Ethnopharmacology), Pharmaceutical Biology, Phytomedicine, Phytotherapy Research, Planta Medica and Journal of Ethnopharmacology, all being leading journals in the field. Thus, this paper is a consensus statement by the editors-in-chief of these main journals in the field of medicinal plant research, ethnopharmacology and natural product research. It cannot be a specific set of requirements; rather, it is a set of guidelines which will hopefully help researchers to develop more robust pharmacological experiments and, thus, to improve the quality of the studies submitted to any journal in the field. Each of the journals undersigning this consensus statement has its own specific requirements and the guidelines published here do not replace nor necessarily include these requirements. Instead, the consensus document is intended as a guide to develop best practice from an early stage, irrespective of any plans for a publication in a specific journal at the end of the study. Therefore, we also hope that it will be adopted more widely in the field

\section{Common concerns in publishing results in the area of phytopharmacology}

From a methodological standpoint, research on bioactive natural products is more challenging than studies performed with synthetic compounds. Nature does not intentionally produce secondary metabolites for human benefit. Rather, the metabolites serve some function for the producers, and the complexity of extracts poses unique challenges.

In Table 1, key areas are covered which require attention in designing, analysing and reporting research. Broadly speaking, the challenges we as editors have seen, include:

- The suitability of specific and accurate models for understanding and predicting an effect (cf. the recommendations by Butterweck and Nahrstedt 2012) 
- Ambiguities about the composition of the preparation under study (i.e., the need for a full botanical/biological definition of the starting material and for adequate characterisation of the extract used)

- Lack of evidence for novelty of the research

- Predictability of the results. Certain types of bioactivity are class-related rather than associated with a specific molecular construct. Thus, the presence of oxygenated functions on aromatic rings results in positive response with chemical (e.g., ORAC and DPPH) and cellular (protection from oxidative degradation of biomolecules) assays. These are chemical reactions that cannot be judged as biologically relevant without ancillary testing

- The specificity of an effect or the lack of such specific effects. It is now a well-known concern that a wide range of compounds are active in a large number of mostly in vitro, but also in vivo models, which, however, cannot be translated into evidence for therapeutic benefits

- The ethical basis of animal experiments is often not evaluated carefully or only limited information on such an assessment is provided. While in vivo studies are generally approved by a relevant ethics committee, such studies are often poorly justified scientifically (Is this study really needed?).

- The relevance, limitations and misinterpretation of statistical significance ( $P$ values) (e.g., Mullane et al. 2015, Ioannidis 2005, cf. also Amrehein et al 2019). We consider statistical significance necessary but pharmacological and physiological relevance are of utmost importance (cf. Comment 2019)

- Limited or no justification for animal studies. In vivo research (and clinical studies) are often not justified in the context of their therapeutic relevance nor are they based on high quality in vitro data. Similarly, in vitro studies have been shown to pose numerous problems with the main concern often being the reporting of irrelevant findings.

Drugability factors such as solubility, stability, and reactivity, normally addressed in the planning of synthetic libraries, are often largely unresolved with libraries of natural products. Compounds from isolation programs are often insoluble, unstable, or embellished with structural elements alien to synthetic drugs, such as the ene-dyine anticancer agents. Such challenges need to be overcome. Pan-assay interference compounds, or PAINS have become a major point for discussion in drug discovery (Baell and Walters 2014). Such compounds 
interact with multiple targets and thus are 'promiscuous' (Hu and Bajorath, 2013). They are of particular concern in enzyme-based assays and we recognise this challenge, but many of the studies which reach the journals brought together here use in vivo and/or cell-based assays which are less likely to be affected. However, the specificity of action remains an important point one needs to consider in phytoharmacology.

Numerous other problems have been identified in the context of pharmacological research. While 'experiments must doubt', we can avoid common mistakes and develop a strategy which is best suited for research in this field today.

We are not addressing in detail the food uses of plants nor at the assessment of a species' toxicity. Nor can chemical or botanical aspects be covered in great detail, but for the latter, clear guidelines are available (Rivera et al 2014).

\section{Approach and methods}

This review is based on an iterative process between the authors. Following the initial idea $(\mathrm{MH})$, a draft checklist was developed which was modified over a range of iterations. While we did not follow a formal Delphi process, during several rounds, responses were aggregated and shared with the group after each round. Individual editors added specific concerns commonly found in the journals they are representing and all then agreed whether this should be seen as a common requirement or not.

\section{Pharmacology and natural product research - common challenges and standards of research}

All journals involved in this consensus project publish papers which contribute to an understanding of the pharmacological effects of complex mixtures and of metabolites derived from them. In the following, we provide a brief overview on the scope of each of these journals:

$>$ Fitoterapia (https://www.journals.elsevier.com/fitoterapia) publishes mainly molecularly-oriented manuscripts on natural products (novel structures or synthesis, identification of mechanisms of action and targets, molecular editing of natural products, and structure-activity relationships). It started to publish research articles in 1930 (predecessor Estratti fluidi titolati), but until ca. 1935 these were occasional 
publications. The journal publishes contributions in seven major areas:

1. Characterization of active ingredients of medicinal plants

2. Development of standardization method for bioactive plant extracts and natural products

3. Identification of bioactivity in plant extracts

4. Identification of targets and mechanism of activity of plant extracts

5. Production and genomic characterization of medicinal plants biomass

6. Chemistry and biochemistry of bioactive natural products of plant origin

7. Critical reviews of the historical, clinical and legal status of medicinal plants, and accounts on topical issues.

- Frontiers in Pharmacology - section Ethnopharmacology

(https://www.frontiersin.org/journals/pharmacology/sections/ethnopharmacology\#) started publishing in 2010 and 'is a worldwide, open access platform for bioscientific, clinical and sociocultural research on medicinal and food plants as well as other natural substances used throughout the world. This multidisciplinary approach is an essential basis for the use of these resources in tomorrow's medicines. Neglected diseases, including such common ones as vector-borne ones, diarrhea or tuberculosis are still commonly treated with herbal medicines. ... A core challenge in pharmacology is the scientific study of the complex products derived from such traditions. Extracts obtained from plants, fungi or animals pose some unique challenges: they are multicomponent mixtures of active, partially active and inactive substances and the activity is often not on a single target.' (Heinrich 2010)

> 'The Journal of Ethnopharmacology (https://www.journals.elsevier.com/journal-ofethnopharmacology) was started in 1989 and publishes original articles concerned with the observation and experimental investigation of the biological activities of plant and animal substances used in traditional medicines of past and present cultures. The journal particularly welcomes interdisciplinary papers with an ethnopharmacological, an ethnobotanical or an ethnochemical approach to the study of indigenous drugs. Reports of anthropological and ethnobotanical field studies fall within the journal's scope. Studies involving pharmacological and toxicological mechanisms of action are especially welcome.'

> Pharmaceutical Biology (https://www.tandfonline.com/loi/iphb20) was started in 1961 (as the 'Quarterly Journal of Crude Drug Research') and is an open access, peer reviewed journal, publishing manuscripts describing high-level research on natural 
medicines, as well as biologically active natural products or their derivatives. Investigations on complex traditional medicine formulas are also welcome. Topics may generally encompass any facet of natural product research related to pharmaceutical biology. Papers dealing with agents or topics related to natural product drugs are also appropriate (e.g., semi-synthetic derivatives). The primary criteria for acceptance and publication are scientific rigor and potential to advance the field.

Some more specific examples of manuscripts falling within the scope of the journal follow:

$>$-Discovery of novel bioactive chemicals from natural sources (including herbal medicines, marine organisms, and microorganisms)

$>$-Structural modification of bioactive natural products and structure-activity relationship studies

$>$-Quality control of herbal medicines

$>$-Pharmacology, pharmacokinetics, toxicity, and clinical studies of natural products and herbal medicines

$>$-Biosynthesis and biocatalysis of natural products

$>$-For studies on complex herbal extracts, it is mandatory to characterize their chemical composition, for instance, HPLC fingerprinting analysis or quantization of major compounds.

Since 1994, Phytomedicine (https://www.journals.elsevier.com/phytomedicine) covers a broad range of topics, including pharmacological, molecular biological, toxicological, pharmacokinetic and clinical studies. It is is primarily a therapy-oriented journal and publishes innovative studies on efficacy, safety, quality and mechanisms of action of specified plant extracts, and their isolated constituents. Phytomedicine aims to facilitate the integration of phytotherapy-related products into conventional medicine. Covered topics include clinical pharmacology and toxicology, neurological disorders, ageassociated disorders, neuropharmacology, endocrine pharmacology, metabolic syndrome and obesity, cancer, immunopharmacology and inflammation, infectious diseases, pulmonary, gastrointestinal, cardiovascular and urogenital diseases, systems biology, safety assessment, pre-clinical toxicology, and drug interactions, pharmacokinetic studies, standardization of herbal preparations, legislation of botanicals, and invited reviews. 
$>$ Since 1987 Phytotherapy Research

(https://onlinelibrary.wiley.com/page/journal/10991573/homepage/productinformatio

n.html) covers all aspects of experimental and clinical pharmacology of plant-derived products. Mechanistic studies on isolated metabolites as well as studies on humans (from case reports to randomized clinical trials), systematic reviews and meta-analysis of clinical trials are particularly welcome. The journal does not publish agricultural, phytochemical, structure elucidation, quality control or botanical identification papers unless they have a pharmacological focus and relevance.

> Planta Medica - Journal for Medicinal Plant and Natural Product Research (https://www.thieme.de/de/planta-medica/aims-and-scope-120123.htm) publishes original research on natural products (including those from marine organisms, fungi as well as micro-organisms) and medicinal plants as well as review articles. It covers the following areas of medicinal plant and natural product research: biological and pharmacological activities; natural product chemistry and analytical studies; pharmacokinetic investigations; and formulation and delivery systems of natural products.

\section{Practical approaches to developing projects and reporting the outcomes}

\section{Development}

As scientists and editors we are often surprised how little effort goes - prior to conducting the experiments - into a thorough assessment of the available literature on a topic. In case of medicinal plant/natural product research, this include the source organism or compound under study as well as the methods and the wider approach. In general, one would expect that a paper to be submitted reports a substantive body of phytopharmacological research and it must be an independent addition to the literature. Based on this, well-defined objectives of research (i.e., a series of clear research questions) or a testable hypothesis should be developed. Detailed planning and design are incorporated into Table 1; the underlying concepts and methods must be clear to all parties involved.

\section{Conducting}


This consensus document cannot be about the specifics of experimental approaches, but all investigators must give consideration to developing the pharmacological element in a project (for a detailed checklist see Table 1). Specifically, this ranges from fundamental points such as including appropriate (positive and negative) controls and ascertaining the full taxonomic validity of the material under investigation (Rivera et al. 2014), to ascertaining that the models used are suitable for the questions being researched (e.g., can specific in silico or in vitro models really correlate with the pharmacological activity of the compound or extract?). The type of extract must be defined in sufficient detail and the specific requirements for this vary from journal to journal.

There are numerous challenges in conducting experiments. As pointed out recently, for example, triplicate experiments may not provide a sufficient data set for calculations of significance (Amrehein et al 2019) and a careful evaluation of the results is needed. Core questions include (cf. Table 1):

- Was the available information before starting the experiments sufficient to set up my hypothesis?

- Was the preparation of the extract done in such a way that potentially active compounds were extracted and remained stable (see the famous example of the identification of artemisinin by Youyou Tu, 2017)

- Are the identified biomarkers really therapeutically relevant or are these analytical (quality) markers?

- Were the right controls included?

- Are predictions in my experiment really feasible and testable (Right model, right concentration)?

- Was there at least one clear prediction based on a dependent variable?

- Often, a local/traditional use is presented as the very basis on which a study is designed. However, what then proceeds is so far removed from the traditional practice, e.g., can the inhalation of a medicinal smoke to treat respiratory infections be represented in the laboratory by the preparation of a methanolic extract of the plant material, surely not. Researchers in the field of evidence-based ethnopharmacology need to ask, does my experimental design mimic, as closely as possible, the local/traditional use and preparation under investigation? 
From the point of editors, publication of negative results flanked by solid supporting positive data is always welcome and will be published. This is indeed the avenue to knowledge, preventing the redoing of scientific experiments, which are inconclusive or 'negative'. Of utmost importance is the fact that a logical question is being asked in a rational manner, and a negative response to the question can be as important as a positive response, as long as the answer is credible and definitive.

\section{Reporting}

In the most simplistic way, we all need to remember that data need to be reported comprehensively but at the same time succinctly (see Table 1). A common problem encountered in reporting is a lack of a critical assessment of the data. Coming back to Claude Bernard, 'Never make experiments to confirm one's ideas, but simply to evaluate them' (Il ne fallait jamais faire des expériences pour confirmer ses idées, mais simplement pour les contrôler; emphasis $\mathrm{MH})$. In other words, science, in general, including phytopharmacological research, aims at demonstrating that a certain preparation is active, but it is the task of researchers to assess whether a pharmacological effect can be found or not. What happens if data do not support my hypothesis? It may but it does not prove that the hypothesis is wrong. It may show that the pharmacological model is too complex and additional experiments need to be conducted. Disproving can very well mean important information is available to share. Therefore, if 'no' activity is found in a certain model and at a certain concentration, this is equally relevant. While such a statement may sound trivial, we have seen many examples now where researchers try to prove that a certain (local or traditional) medicine is active, but use a scientific approach that is fundamentally flawed.

It needs to be remembered that the results obtained are pre-determined and depend on the methods used. For example, for many years antimicrobial activity was determined through biocidal and biostatic assays. If a plant extract was not active in these assays it was discarded and labelled as not being antimicrobial active. It has now emerged that many botanicals may rather exert antimicrobial activity through a different mechanism of action, e.g., interfering with bacterial quorum sensing which would not be detected in assays acutely focusing on a "killing effect" only.

\section{Ethical considerations}


We cannot enter into the large area of research ethics, but simply want to draw attention to the need for compliance with a large range of ethical standards including those for access to biological materials (Heinrich and Hesketh 2018), the conduct of research (including authorship; justification of animal experiments) and its reporting (publishing ethics, see the COPE Guidelines -

http://publicationethics.org/files/International\%20standards_authors_for\%20website_11_Nov 2011.pdf and https://www.elsevier.com/authors/journal-authors/policies-and-ethics / https://www.frontiersin.org/about/author-guidelines / https://www.thieme.de/de/zeitschriftpalliativmedizin/publication-ethics-140346.htm / https://authorservices.wiley.com/editors/ethical-guidelines/index.html ).

\section{Conclusions}

If '[e]xperimenters must doubt', as we had highlighted in the introduction using Claude Bernard's classical work, with this consensus document we want to ascertain that experimenters (researchers) understand what is needed to successfully develop, conduct and report research on bioactive preparations derived from natural sources. The overarching answer has again been given by Claude Bernard: '.... either the experimenter's hypothesis will be disproved or it will be proved by experiment. When experiment disproves its preconceived ideas, the experimenter must discard or modify it.' (Bernard 1957: 52).

This paper provides qualitative standards for reproducibility and significance of bioactivity data on natural products/extracts across the most popular scientific journals used to disseminate such results. The driving motivation of all editors is to provide clear and transparent guidelines for a fair review process that meets criteria for responsible dissemination at a high level of good publishing practice. All editors are aware that contemporary research is interdisciplinary and driven by much larger datasets as compared with the last two decades, and with these guidelines, we want to ascertain that the standards in the field of phytopharmacology keep up with the more general developments in pharmacology. At the same time, no state-of-the-art highly sophisticated technique can provide meaningful and reproducible data if the fundamental requirements of research are not fulfilled. In the field of phytopharmacology, this perspective highlights some specific challenges. 
In bringing together journals with a common focus and similar opportunities as well as challenges our statement as editors of scientific journals in the field is novel. Previous generations of researchers have also been confronted with similar questions. However, it has become more prominent in recent years, where data acquisition and analysis seems easier, but also more reliant on specialists who only support the natural product scientist in an interdisciplinary team. Recently, there has been an unprecedented number of papers withdrawn or retracted from the scientific literature. Therefore, all editors must ask the question of accurate data handling and request precision in a rapidly changing technical and digital world.

In the field of ethnopharmacology/medicinal plant research, scientists have special professional and social responsibilities. Data describing biological activity may reach the general public who use these results as a guide to treat various diseases, many of which are very serious. Use of excessively high doses, poorly characterised extracts, and claims for effects of extracts which are not commonly used, are examples of factors that may be used inappropriately if they are not reported and discussed adequately. Inadequate toxicological data may lead to harming patients. It is our responsibility to deliver new high quality and reproducible findings for the future benefit of patients and for the development of natural product research on new or known drug substances.

In conclusion, with this statement, we want to encourage all members of the scientific community to embrace strategies that enable further evidence-based development of natural products using a rigorous scientific approach. Our job is not to fill the literature with meaningless and mundane reports of nebulous significance. Our goal is to assist researchers in disseminating findings in a continuum that moves solid scientific knowledge from the level of the research bench to the rest of the world.

Table 1: General requirements for developing, conducting and reporting pharmacological research on medicinal plants and natural products (phytopharmacology)

\begin{tabular}{|l|l|l|}
\hline $\begin{array}{l}\text { From idea } \\
\text { to new } \\
\text { knowledge }\end{array}$ & Key questions & Specific approaches / topics \\
\hline Developing & How relevant is the & Background assessment of the literature on the \\
\hline
\end{tabular}




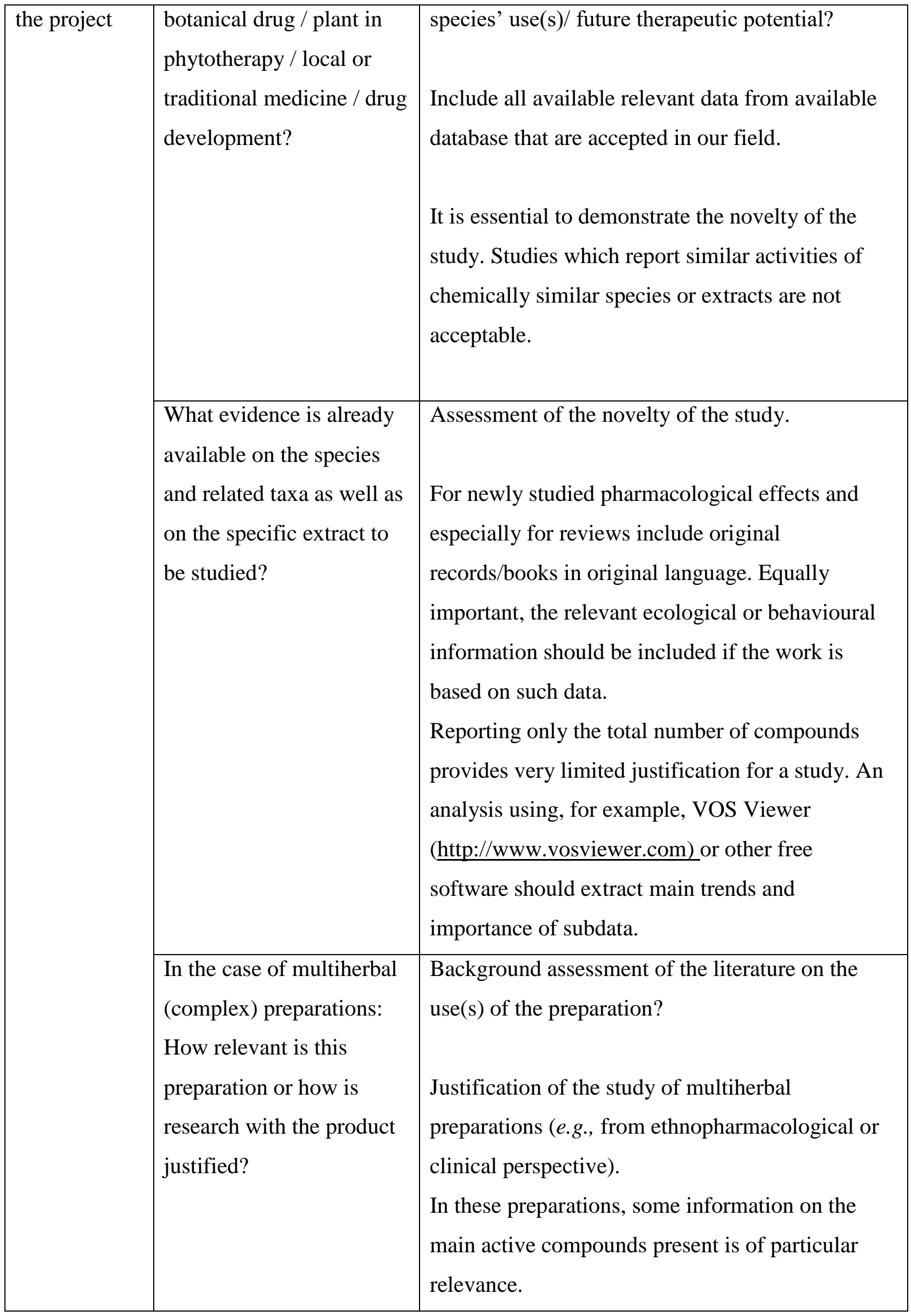




\begin{tabular}{|c|c|}
\hline & $\begin{array}{l}\text { Some indication should be provided on why the } \\
\text { authors believe the work can be reproduced or } \\
\text { expanded based on others obtaining an equivalent } \\
\text { product. The emergence of meta-barcoding proves } \\
\text { to be highly efficient in characterizing complex } \\
\text { herbal formulations. }\end{array}$ \\
\hline $\begin{array}{l}\text { Can the plant be sourced } \\
\text { sustainably? }\end{array}$ & $\begin{array}{l}\text { Assessment of potential sourcing problems / } \\
\text { sustainability concerns (a concern which is of } \\
\text { particular relevance for collections from the wild } \\
\text { (see also Materials and Methods on the botanical } \\
\text { material). }\end{array}$ \\
\hline $\begin{array}{l}\text { Are there any potential } \\
\text { ethical aspects which need } \\
\text { to be resolved prior to the } \\
\text { start of the project? }\end{array}$ & $\begin{array}{l}\text { Justification of the model (in vivo), of sustainable } \\
\text { sourcing (see below), compliance with } \\
\text { international treatise (Nagoya etc.) and national } \\
\text { regulations of sourcing and benefit sharing. The } \\
\text { use of animals (incl. insects) or other organisms } \\
\text { (bacteria) must be justified in the context of } \\
\text { novelty of the research (see below). }\end{array}$ \\
\hline $\begin{array}{l}\text { What is the best } \\
\text { overarching } \\
\text { pharmacological } \\
\text { methodology (research } \\
\text { strategy)? }\end{array}$ & $\begin{array}{l}\text { Definition of specific methods and tools including } \\
\text { in vitro or in vivo approaches. }\end{array}$ \\
\hline $\begin{array}{l}\text { In vivo studies: Which } \\
\text { methods have the highest } \\
\text { value for prediction and } \\
\text { will lead to therapeutically } \\
\text { relevant results? }\end{array}$ & $\begin{array}{l}\text { Ascertain that the baseline data are sufficiently } \\
\text { robust and sound and use the 3Rs for best practice } \\
\text { using animals [Refinement - improve the quality } \\
\text { of scientific papers using animal experimentation } \\
\text { - reduction - diminish the number of animals } \\
\text { needed in animal experimentation and improve } \\
\text { animal welfare, and replacement - substitute } \\
\text { animal experiments with other approaches. } \\
\text { The repetitive study of similar preparations or }\end{array}$ \\
\hline
\end{tabular}




\begin{tabular}{|c|c|}
\hline & $\begin{array}{l}\text { compounds has rightfully been seen as one of the } \\
\text { main problems in the large-scale use of animals, } \\
\text { especially in academic research, and may be the } \\
\text { easiest of the three Rs to tackle. }\end{array}$ \\
\hline $\begin{array}{l}\text { In case of plants used } \\
\text { based on indigenous / } \\
\text { traditional medical } \\
\text { concepts: Can the } \\
\text { traditional use be } \\
\text { meaningfully represented } \\
\text { in a pharmacological } \\
\text { model? }\end{array}$ & $\begin{array}{l}\text { Assessment of the 'translatability' of traditional } \\
\text { medical concepts and uses, even though the } \\
\text { translation of traditional medicine concepts in the } \\
\text { Western medicine will often be problematic. }\end{array}$ \\
\hline $\begin{array}{l}\text { In case of mechanistic } \\
\text { pharmacological studies: } \\
\text { How can the mechanism } \\
\text { be evaluated for } \\
\text { chemically complex } \\
\text { preparations? }\end{array}$ & $\begin{array}{l}\text { Assess whether the assays are suitable for complex } \\
\text { mixtures (including specificity of action of } \\
\text { common constituents). }\end{array}$ \\
\hline $\begin{array}{l}\text { Traceability of the source } \\
\text { material is of critical } \\
\text { relevance for the } \\
\text { validation of published } \\
\text { data. }\end{array}$ & $\begin{array}{l}\text { Details on the sourcing of the material are } \\
\text { essential for future research and development (see } \\
\text { below), also for those samples which are sourced } \\
\text { from commercial suppliers. }\end{array}$ \\
\hline $\begin{array}{l}\text { How can species, } \\
\text { compounds been } \\
\text { registered or are already } \\
\text { with accession codes in } \\
\text { data bases? }\end{array}$ & $\begin{array}{l}\text { All species (Rivera et al. 2014) or compounds or } \\
\text { proteins need to be named using the existing } \\
\text { international standards / accession codes in } \\
\text { databases such as PubMed (chemical structure, } \\
\text { substances, bioassay, Genes, ...) } \\
\text { https://www.ncbi.nlm.nih.gov. } \\
\text { Medicinal plant name service } \\
\text { (http://mpns.kew.org/mpns-portal/) or another }\end{array}$ \\
\hline
\end{tabular}




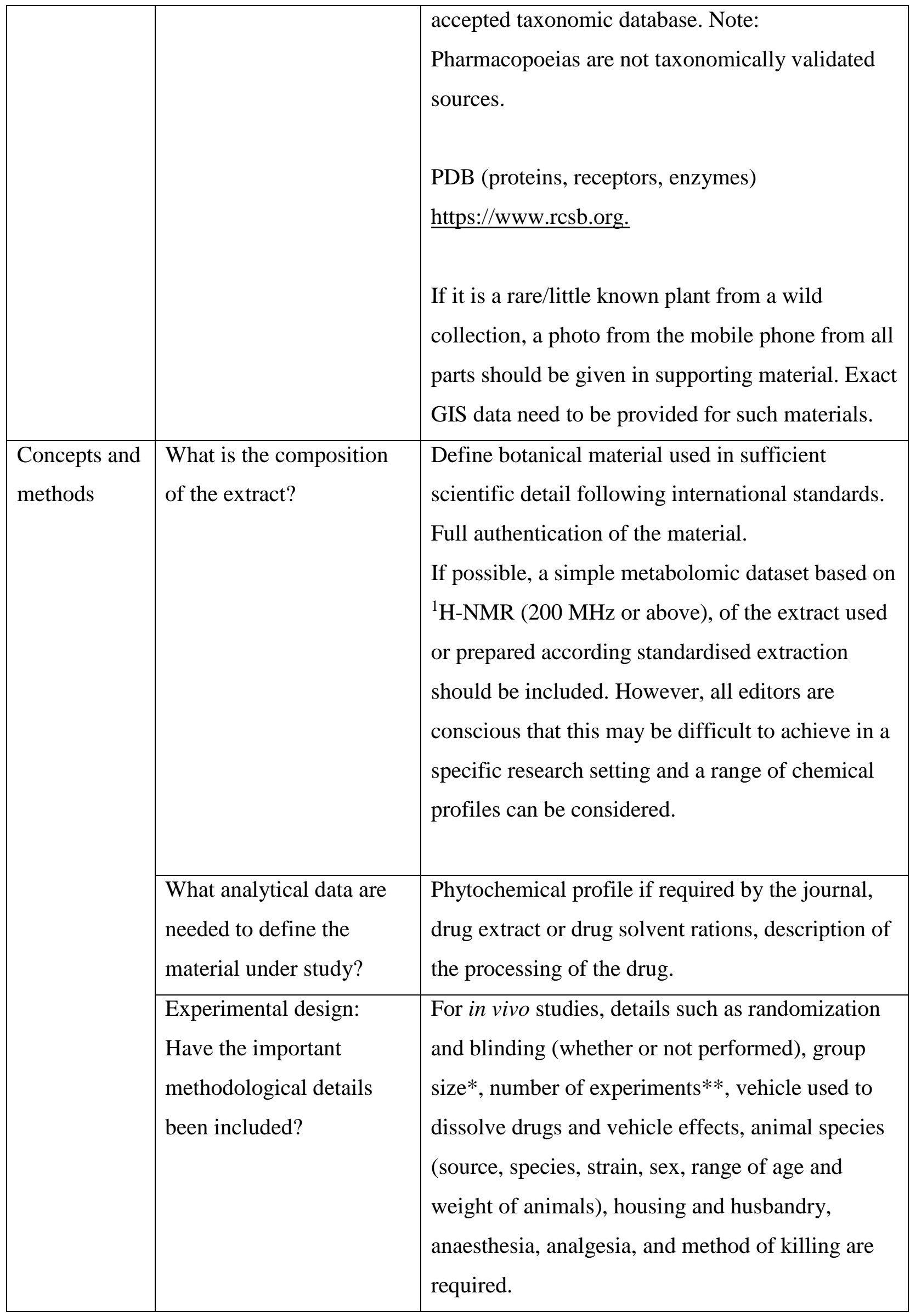




\begin{tabular}{|c|c|}
\hline & $\begin{array}{l}\text { From the description, it must be clear that the } \\
\text { study complies with the } 3 \mathrm{R} \text { of animal research } \\
\text { (reduction, refinement, replacement), which, } \\
\text { however, must not result in a loss of the statistical } \\
\text { power of the experiment. }\end{array}$ \\
\hline $\begin{array}{l}\text { What pharmacological } \\
\text { methods are suitable and } \\
\text { can be implemented / used } \\
\text { in-house? }\end{array}$ & $\begin{array}{l}\text { Review of the approach and relevant literature on } \\
\text { potential methods. }\end{array}$ \\
\hline $\begin{array}{l}\text { What is the current } \\
\text { methodological state-of- } \\
\text { the-art in the context of } \\
\text { the specific research } \\
\text { questions? }\end{array}$ & $\begin{array}{l}\text { Defining what would be the optimal approach } \\
\text { from a pharmacological perspective (and see } \\
\text { above providing a scientific justification for } \\
\text { animal experiments). }\end{array}$ \\
\hline $\begin{array}{l}\text { What are the most } \\
\text { appropriate controls? }\end{array}$ & $\begin{array}{l}\text { Define positive and negative controls and use } \\
\text { preferably standard drugs from clinics. } \\
\text { The standard need to show significant activity in } \\
\text { the assay and must have been validated and used } \\
\text { over the years (e.g., penicillin G, amphoterin B, } \\
\text { vincristine). This will also allow the calculation of } \\
\text { the selectivity index, where applicable (e.g., } \\
\text { cytotoxicity, anti-protozoal effects). }\end{array}$ \\
\hline $\begin{array}{l}\text { What dose range is } \\
\text { appropriate and of } \\
\text { potential therapeutic } \\
\text { relevance? }\end{array}$ & $\begin{array}{l}\text { Definition of dose range and explanation of the } \\
\text { rationale provided for the selection of doses, route } \\
\text { and frequency of drug administration. } \\
\text { For compounds/extracts already used in humans, it } \\
\text { is critical to have a dose-response curve in the } \\
\text { experimental set up that includes the usual dose in } \\
\text { humans. Differences in doses that normalize } \\
\text { interspecies variation should be taken into } \\
\text { account.*** } \\
\text { It is not possible to define an exact upper cut-off } \\
\text { dose, the dose range tested must still be }\end{array}$ \\
\hline
\end{tabular}




\begin{tabular}{|c|c|}
\hline & $\begin{array}{l}\text { pharmacologically relevant. In many cases, a dose } \\
\text { range of } 100 \text { - } 200 \mathrm{mg} / \mathrm{kg} \text { for in vivo studies of } \\
\text { extracts (p.o. with the upper limit being much } \\
\text { lower for i.p. and i.m. applications) and of } 100 \text { - } \\
200 \mu \mathrm{g} / \mathrm{ml} \text { should be assumed as being the upper } \\
\text { limit for meaningful pharmacological studies. For } \\
\text { pure compounds, a much lower dose range should } \\
\text { be considered (ca. } 50 \mathrm{mg} / \mathrm{kg} \text { for in vivo studies of } \\
\text { extracts (p.o.) and of } 30 \text { - } 50 \mu \mathrm{M} \text { for in vitro } \\
\text { studies). The use of higher doses needs to be } \\
\text { justified in detail. } \\
\text { The evaluation of doses / concentrations that are } \\
\text { much higher than what can be achieved in humans } \\
\text { may be helpful in elucidating off-target effects and } \\
\text { toxicities only, but it has no translational value } \\
\text { from a therapeutic viewpoint. }\end{array}$ \\
\hline $\begin{array}{l}\text { What dose causes } \\
\text { toxicity? }\end{array}$ & $\begin{array}{l}\text { Selective is the best basis for assessing the } \\
\text { relevance of the data. In addition, review the } \\
\text { literature to check the maximal tolerated dose (or } \\
\text { provide it experimentally) in order to define a } \\
\text { therapeutic window. }\end{array}$ \\
\hline Statistical evaluation & $\begin{array}{l}\text { Are the statistical tools adequate for the } \\
\text { experimental approach? }\end{array}$ \\
\hline $\begin{array}{l}\text { Does the manuscript } \\
\text { report a substantive body } \\
\text { of phytopharmacological } \\
\text { research? }\end{array}$ & $\begin{array}{l}\text { Assess - also based on the specific journal's } \\
\text { requirements - the breadth and detail of the data } \\
\text { generated? }\end{array}$ \\
\hline $\begin{array}{l}\text { Does the body of reported } \\
\text { pharmacological effects } \\
\text { cover a coherent area of } \\
\text { activities, which allows a } \\
\text { better understanding of }\end{array}$ & $\begin{array}{l}\text { Comparison of the experimental data, including an } \\
\text { assessment of potentially contradictory } \\
\text { experimental data. }\end{array}$ \\
\hline
\end{tabular}




\begin{tabular}{|c|c|c|}
\hline & $\begin{array}{l}\text { the species' therapeutic } \\
\text { benefits? }\end{array}$ & \\
\hline \multirow[t]{5}{*}{$\begin{array}{l}\text { Reporting } \\
\text { data and } \\
\text { outcomes }\end{array}$} & $\begin{array}{l}\text { Are the resulting } \\
\text { pharmacological data } \\
\text { potentially linked to } \\
\text { common (ubiquitous) } \\
\text { compounds with known } \\
\text { effects? }\end{array}$ & $\begin{array}{l}\text { Evaluation of the novelty of the information in the } \\
\text { context of phytochemical/phytopharmacological } \\
\text { data }\end{array}$ \\
\hline & $\begin{array}{l}\text { How specific is the } \\
\text { pharmacological effect? }\end{array}$ & $\begin{array}{l}\text { In order to establish therapeutic benefits, } \\
\text { selectivity data are essential [see also Baell and } \\
\text { Walters (2014) and Hu and Bajorath, 2013)] } \\
\text { which caution against spurious bio-assay } \\
\text { interferences especially in enzyme-based assays. }\end{array}$ \\
\hline & $\begin{array}{l}\text { In the case of anti- } \\
\text { microbial effects: Does } \\
\text { the study follow the } \\
\text { widely accepted standards } \\
\text { for microbiological } \\
\text { testing? }\end{array}$ & $\begin{array}{l}\text { Quality assessment of methods. Zones of } \\
\text { inhibition alone are generally not adequate. }\end{array}$ \\
\hline & $\begin{array}{l}\text { Applying suitable } \\
\text { statistics. }\end{array}$ & $\begin{array}{l}\text { Triplicates are the lowest number of data for } \\
\text { statistics. Microsoft Excel is an inappropriate } \\
\text { statistic software (in fact, not a statistical tool as } \\
\text { such) and cannot be used as a statistic method in } \\
\text { the experimental part. }\end{array}$ \\
\hline & Anti-inflammatory effects. & $\begin{array}{l}\text { The term "inflammation" reflects a complex } \\
\text { physiological situation that involves many cell } \\
\text { types and signalling pathways. Thus, authors } \\
\text { should use the term "anti-inflammatory" with } \\
\text { caution and should consider the in vivo and/or in } \\
\text { vitro model used to study "inflammation" very } \\
\text { carefully. Similar considerations are needed when } \\
\text { reporting other pharmacological interventions in } \\
\text { complex physiological contexts. }\end{array}$ \\
\hline
\end{tabular}




\begin{tabular}{|c|c|}
\hline $\begin{array}{l}\text { Use of commercially } \\
\text { available kits. }\end{array}$ & $\begin{array}{l}\text { The use of such kits must be validated, especially } \\
\text { in the case of complex mixtures, to provide } \\
\text { evidence for the specificity of the kit. } \\
\text { Fluorescence detection can be particularly } \\
\text { problematic. }\end{array}$ \\
\hline $\begin{array}{l}\text { Antiproliferative/cytotoxic } \\
\text { activity: is the effect } \\
\text { selective and } \\
\text { pharmacologically } \\
\text { relevant? }\end{array}$ & $\begin{array}{l}\text { Show that extracts, compounds have selectivity } \\
\text { and are not "anti-life" drugs. Ideally, a comparison } \\
\text { of the effect between tumour and healthy cells (if } \\
\text { available), especially when the effect is observed } \\
\text { at high concentrations, should be provided. There } \\
\text { should be some confidence that the tumour and } \\
\text { normal cells are comparable in terms of growth } \\
\text { rate, etc., to avoid artefacts. } \\
\text { It is essential to clearly separate out anti-cancer } \\
\text { research (in general in vivo) and research on cyto- } \\
\text { toxic pro-apoptotic effects. The relevance of a cell } \\
\text { line must be justified. Also, make sure to } \\
\text { distinguish between chemopreventive agents and } \\
\text { anti-cancer agents, and use a proper reference. } \\
\text { Compounds like platinum derivatives have poor } \\
\text { activity in cellular assays, and their use leads to } \\
\text { the wrong claim that cytotoxicity outperforms or is } \\
\text { close to the one of a validated anticancer agent. }\end{array}$ \\
\hline $\begin{array}{l}\text { In the case of antioxidant } \\
\text { activity: what } \\
\text { methodology has been } \\
\text { used? }\end{array}$ & $\begin{array}{l}\text { Relevant antioxidant activities arise from } \\
\text { pharmacologically-relevant in vivo or cell-based } \\
\text { models. There is no evidence for therapeutic } \\
\text { benefits on the basis of chemical anti-oxidant } \\
\text { assays like the DPPH or FRAP and - in line with } \\
\text { the policies of many journals, the journals do not } \\
\text { accept them as a main pharmacological assay, but } \\
\text { they remain useful as a chemical screening tool. }\end{array}$ \\
\hline $\begin{array}{l}\text { Has the research question } \\
\text { been answered / the }\end{array}$ & $\begin{array}{l}\text { An objective is not a hypothesis. Define your } \\
\text { hypothesis or research question first and come }\end{array}$ \\
\hline
\end{tabular}




\begin{tabular}{|c|c|c|}
\hline & hypothesis evaluated? & $\begin{array}{l}\text { back to it in the Results and Discussion part. } \\
\text { Assess outcomes in the context of previous } \\
\text { knowledge. }\end{array}$ \\
\hline & $\begin{array}{l}\text { Have limitations or } \\
\text { alternative interpretation } \\
\text { of the data been } \\
\text { considered? }\end{array}$ & $\begin{array}{l}\text { Highlight limitations and assessment of alternative } \\
\text { interpretation. }\end{array}$ \\
\hline & $\begin{array}{l}\text { Does the research have } \\
\text { clinical implications? }\end{array}$ & Definition of the field/disease of application. \\
\hline $\begin{array}{l}\text { Evaluation } \\
\text { and } \\
\text { conclusions }\end{array}$ & $\begin{array}{l}\text { What other important } \\
\text { implications does this } \\
\text { research have? }\end{array}$ & $\begin{array}{l}\text { Future research needs will, of course, depend on } \\
\text { the context of the research, and while we do not } \\
\text { want to provide detailed guidelines, any } \\
\text { conclusion relating to future research needs must } \\
\text { be specific and based on the data reported. }\end{array}$ \\
\hline
\end{tabular}

* Group sizes should be equal by design, and any variation, due to experimental losses or violation of predetermined exclusion criteria, must be explained (see for details Curtis et al. Br J Pharmacol. 2015 Jul;172(14):3461-71)

**The exact group size (n) for each experimental group/condition must be provided and the number of experiments (n) refers to independent values, not replicates [e.g., 3 samples each run in triplicate is $\mathrm{n}=3$ not $\mathrm{n}=9$ (see for details Curtis et al. Br J Pharmacol. $2015 \mathrm{Jul} ; 172(14): 3461-71)]$

***see Nair AB, Jacob S. (2016) A simple practice guide for dose conversion between animals and human. J Basic Clin Pharm. 7(2):27-31. 


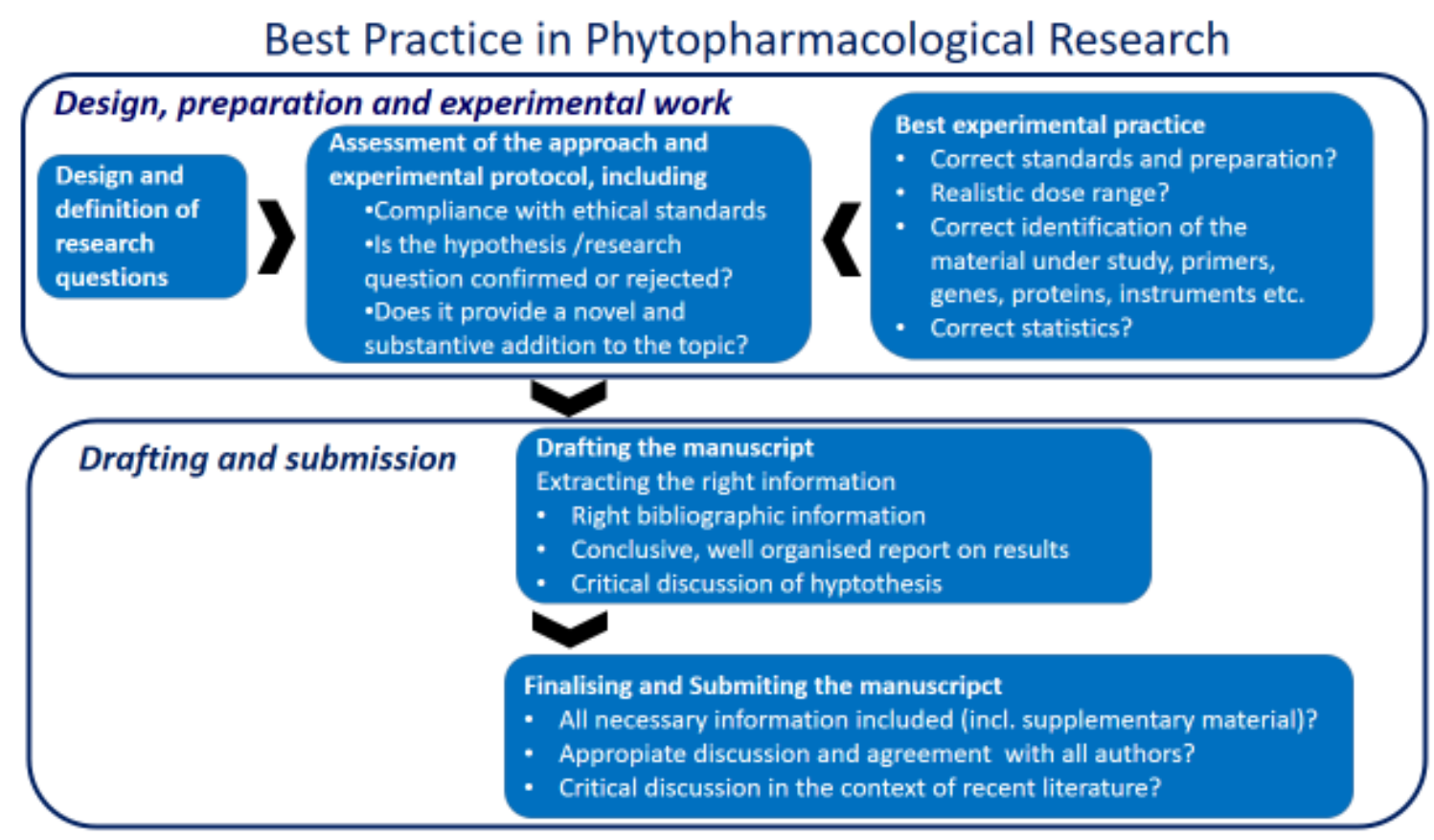

Figure 1: Scientific publishing as an iterative process of project development, data generation and assessment, evaluation and manuscript development.

\section{Acknowledgment}

A fact that authors may not fully appreciate is that timely publication of a manuscript reflects the crescendo of an effort orchestrated by a myriad of players. To some extent, we, as editors, may be viewed as the conductors of our respective orchestras. As with a symphony, the orchestra involves the seamless cooperation of authors, peer reviewers, editorial boards, associate and managing editors, type setters, and, ultimately, a publisher. Without this team effort, the process would resemble a cacophony. Accordingly, we express our deep appreciate to the enumerable contributors who help us bring novel scientific discoveries to the attention of the scientific community and, ultimately, all of humanity, in a unique and privileged manner that is indelible. Scientific literature is indelible. Scientific literature provides the building blocks of the future. It is hoped the reflections we provide in the current report will help to assure natural product research continues to play a dominant role in promoting human health and other forms of socioeconomic benefit, as it has since time immemorial.

\section{References}

Amrhein V, Greenland S, McShane B. (2019) Scientists rise up against statistical significance. Nature. 567(7748):305-307. doi: 10.1038/d41586-019-00857-9.

Baell, J., Walters, M.A. (2014). Chemical con artists foil drug discovery Nature 513 (7519), pp. 481-483 
Bernard, Claude (1957). An Introduction to Experimental Medicine. New York Dover Pub. (French original 1865 Introduction à l'étude de la médecine expérimentale. Paris,J. L. Baillière et Fils)

Bodeker G, Ong CK, Grundy C, Burford G, Shein K (2005) WHO Global Atlas of Traditional, Complementary, and Alternative Medicine. World Health Organization, Kobe, Japan

Butterweck, V, Nahrstedt A. (2012) What Is the Best Strategy for Preclinical Testing of Botanicals? A Critical Perspective. Planta Med 2012; 78: 747-754

Comment: Retire statistical significance. (2019) Nature. 567, 305-307.

Curtis et al. (2015) Experimental design and analysis and their reporting: new guidance for publication in BJP Br J Pharmacol. 172(14):3461-71)

Harper PS (2006) The discovery of the human chromosome number in Lund, 1955-1956. Hum Gen . 119 (1-2), 226-232.

Heinrich, M.(2010) Frontiers in Ethnopharmacology - Grand Challenges. Frontiers in Pharmacology 1, Art. 8 (10.3389/fphar.2010.00008)

Heinrich, M., A. Hesketh (2018) 25 years after the 'Rio Convention'-Lessons learned in the context of sustainable development and protecting indigenous and local knowledge. Phytomedicine 53:332-343. doi: 10.1016/j.phymed.2018.04.061.

Heinrich, M. (2013) Phytotherapy. Encyclopaedia Britannica (Online). New York Hooijmans, C.R., Leenaars m., Ritskes-Hoitinga m., (2010) A Gold Standard Publication Checklist to Improve the Quality of Animal Studies, to Fully Integrate the Three Rs, and to Make Systematic Reviews More Feasible. ATLA 38, 167-182,

Hooijmans CR, Rovers MM, de Vries RB, Leenaars M, Ritskes-Hoitinga M, Langendam MW. (2014) SYRCLE's risk of bias tool for animal studies. BMC Med Res Methodol 2014; $14: 43$

Hu, Y, Bajorath, J. (2013) What is the Likelihood of an Active Compound to Be Promiscuous? Systematic Assessment of Compound Promiscuity on the Basis of PubChem Confirmatory Bioassay Data. AAPS J 15:808-815.

Ioannidis JPA (2005) Why most published research findings are false. PLoS Med 2(8): e124. Mullane, K., Enna, S.J., Piette, J., Williams, M., 2015. Guidelines for manuscript submission in the peer-reviewed pharmacological literature. Biochem. Pharmacol. 97, 225-235.

Rivera, D., R. Allkin, C. Obón, Fr. Alcaraz, R. Verpoorte, M. Heinrich (2014) What is in a name? The need for accurate scientific nomenclature for plants. Journal of Ethnopharmacology 152: 393-402. doi.org/10.1016/j.jep.2013.12.022i 
Tu, Youyou (2017) From Artemisia annua L. to Artemisinins. The Discovery and Development of Artemisinins and Antimalarial Agents. Elsevier (Academic Press) 4 WHO (2005) National policy on traditional medicine and regulation of herbal medicines:

Report of a WHO global survey. World Health Organization, Geneva 